\title{
Impact of Land Acquisition on the Livelihoods: The Case of Gilibina-Akuna-Agita-Merewo-Besikiya Road Project Telemet Woreda, North Gondar Zone, Amhara region, Ethiopia
}

\author{
Getahun Abebe (MSC) \\ Amhara National Regional State Road and Building Design Construction supervision Works Enterprise
}

\begin{abstract}
Gilibina_Akuna_Agita_Merewo_Besikiya road project is located in Amhara National Regional State, North Gondar Administrative Zone, Telemte woreda.

The settlement pattern of the population residing in the project Woreda is dispersed and mainly concentrated in rural settlements that are mainly at lower level of socio economic status. The project influence Woreda lack adequate social services and other infrastructural services, such as road and communication networks.

The total length of the ro ad project is $98.06 \mathrm{~km}$ and is Design Standard (DC3).

The construction of the project road as per the route selection study and Environmental and Social Impact Assessment (ESIA) will improve the livelihood of the local populations that are crossed by the road project. It could also contribute to the growth and development of trade and urban centers, improvement of crop and livestock production and its marketing network. The natural resource and human resource potentials are also highly important in contributing to the development of the project area.

The project road is expected to have both positive and negative impacts in the direct Project Influence Area (PIA), as well in the indirect influence area. The potential social impacts will be quicker felt in the direct influence area. The adverse (or negative) environmental and social impacts are very minimal and could not make significant impacts that will impede the life of the local population.

The proposed project road is in harmony with all the national development policies and strategies of Ethiopia, and fulfils all requirements set forth both by the Federal and Regional Governments.

The land acquisition report presents the policy, legal and Administrative framework; the valuation measures, the compensation payment to be made for the PAPs including restoration measures, and it also establishes methodologies for compensation estimate and payment. The basis of the land acquisition report is a socio economic assessment of the livelihoods that will be affected due to the construction of the project road which include the number of Project Affected Persons, the size of affected properties and asset.
\end{abstract}

DOI: $10.7176 / \mathrm{JESD} / 10-1-03$

\section{Summary of Policy, Legal and Administrative Framework}

The policy, legal and administrative framework analyses the policies that are pertinent for resettlement/rehabilitation and compensation payment that are issued by the Federal Democratic Republic of Ethiopia (FDRE) and it also reviews international financiers policies that are relevant to the project.

The Ethiopian Roads Authority (ERA) which is the holder of the project has prepared Resettlement/Rehabilitation Policy Framework (RPF), which serves as a policy document and guideline for resettlement and rehabilitation of Project Affected Persons due to the construction of road projects. It also establishes the principles for the valuation and compensation payment. The RPF ensures that Project Affected Persons (PAP) will not be impoverished due to the adverse social impacts induced by road projects and that PAPs should be compensated for loss of assets at replacement cost and be assisted in case of relocation or resettlement.

In the review of legal and policy framework, land tenure issues are discussed in relation to the preparation this RAP. In Ethiopia, land is a public property and that no individual person has the legal right to ownership. Since there is no private ownership of land in Ethiopia, and hence, rural or urban land could not be sold or mortgaged or transferred; citizens have only usufruct right only over land. A usufruct right gives the user of the land the right to use and the right to benefit from the fruits of her/his labour which may be crops, trees, etc. found on the land or any permanent works such as buildings etc. Loss of farmland is one of the impacts observed in the upgrading of the project road corridor; however, no compensation is made for loss of land. Compensation will be made loss of crops and infrastructures and investments carried out on farmland.

Regarding expropriation of land for public use, the Federal Democratic Republic of Ethiopia (FDRE) has issued two proclamations. The first one being Proclamation No.455/2005, which deals about the expropriation of land holdings for public purposes and payment of compensation and second on is Council of Ministers regulation No.135/2007, which details and basis on the payment of compensation for property situated on land holdings expropriated for public purposes.

The content of this RAP is within Ethiopia's existing legal and administrative framework; however, it 
also makes reference to international financier policies such as the World Bank (WB) policy on involuntary resettlement (OP4.12). Generally, the project is fully prepared on the basis of policies and regulations of the FDRE.

\section{Summarized Project Impacts}

The potential positive and negative social impacts created by the construction of the project road are identified through field surveys, meetings and discussions held with Project Affected Household heads /Project Affected Persons (PAPs), Government officials and experts; and also by reviewing the route selection report of the project and other studies.

The construction of the project road will contribute to growth and development in the project area in bringing progress and improvement both in social development and economic growth. In the long term, it will create development impacts and incentive that will bring about socio economic growth and changes and improved quality of life for the people residing in the project area. Economically, it is expected to increase the utilization of agricultural inputs and services that will result in increased production (crop and livestock) and anticipated to bring higher farm gate prices for local produce.

The construction of the project road, in the short and medium term it will create impacts such as increase and improve in the availability of transport services and which may lead to reductions in vehicle operating cost, transport and time costs for passenger and for freight transports.

In addition to the positive impacts there will be a number of negative impacts, such as, loss of productive assets, such as, loss of strip of farm land and income; loss of housing; spread communicable diseases (Malaria), spread of Sexually Transmitted Disease (STD) and HIV/AIDS, growth of squatters and uncontrolled settlements, and spoil dumping on farm lands and near water points.

In the project road corridor 497 households will be affected by the project construction due to loss of farmland, houses, trees and fences which are within the project right-of-way. Of the total affected household's 103 households having family members of about 566.5 will be relocated as the result of loss of their residential and business houses. The average household members/family members are assumed to be 5.5.

Table 1 Project affected households

\begin{tabular}{|l|l|c|c|c|}
\hline \multirow{2}{*}{ sr.no } & Impacts & \multicolumn{3}{|c|}{ Affected households } \\
\cline { 3 - 5 } & & Males & Females & Total \\
\hline 1 & Loss of farmland & 333 & 23 & 356 \\
\hline 2 & Loss of houses & 80 & 23 & 103 \\
\hline 3 & Loss of fence & 28 & 10 & 38 \\
\hline & Total & 441 & 56 & 497 \\
\hline
\end{tabular}

As it has been observed there is possibility that a household in the road corridor will be affected two or more times due to loss of houses, fence, trees and strip of farmland.

Hence, the actual number of project affected households will be much lower from the indicated total affected households. As the result this total affected households comes to be 256 and particularly project affected households who will lose both residential and business houses will be 103 (Of the affected houses, 11 are business houses and the rest 91 are residential houses.)

The above affected households will be compensated for their lost houses at a replacement cost and also will be compensated for their lost income. Some of the above households (PAPs) will lose their hoses fully and others partially depending on the impact type and size on each of the houses affected due to the widening of the ROW. The Right- of-Way width adopted for the project road is the road way cross-section design width up to construction limit plus working space width on both sides.

Moreover, the following impacts take place on public and government properties and utilities.

Table 2 Project affected public and government properties

\begin{tabular}{|l|l|l|l|}
\hline No. & Impacts & Number & In $\mathrm{M}^{2}$ \\
\hline I & Buildings & & \\
\hline 1 & Public toilets & 1 & 16 \\
\hline 2 & School buildings & 2 & 96 \\
\hline 3 & Health center/post & 1 & 48 \\
\hline
\end{tabular}

\section{Main Findings}

The main findings table includes the number of affected HH by gender and total number of PAPs, affected properties by type and size which includes housing structures and fences, farmland, and different tree species. 
Table 3 Summary impact by type

\begin{tabular}{|c|c|c|c|}
\hline Sr.n & Type of Impact & Unit & Quantity \\
\hline & $\begin{array}{l}\text { All affected Households (due to loss of houses, farmland, trees, fence and other } \\
\text { structures) }\end{array}$ & & 256 \\
\hline 1.1 & Total male Household heads & No. & 233 \\
\hline 1.2 & Total female Household Heads & No & 23 \\
\hline 1.3 & Total household/family members (5.5 households) & No. & 1408 \\
\hline 2 & Affected households due to loss of houses & No & 103 \\
\hline 2.1 & Male household heads & No. & 80 \\
\hline 2.2 & Female household heads & No & 23 \\
\hline 2.3 & Household/family members & No. & 566.5 \\
\hline & Area of farmland affected & Hectare & 34.5 \\
\hline & Length of affected fences (various type) & Meter & 134 \\
\hline
\end{tabular}

\section{INTRODUCTION}

\section{Ethiopian Road Sector Development Program (ERSDP)}

Ethiopia's road network comprises about $46,812 \mathrm{~km}$ of classified roads including about $6,938 \mathrm{~km}$ of asphalt roads, with a road density per 1000 person was 0.57 or road density per 1000 sq.km was 42.6 . (Source: ERA.2009)

Ethiopia's access to ports, markets and services is amongst the lowest in Sub-Saharan Africa. To address these problems and development constraints caused by poor condition and restricted access, the Government of Ethiopia formulated, in 1996, a ten year Road Sector Development Program (RSDP).

Since then road investments are being planned and implemented in Ethiopia within the framework of this Program. These investments include the rehabilitation of or upgrading of the main trunk, link and rural roads and construction of new roads to expand the network.

The Gilibina-Akuna-Agita-Merewo-Besika road project is geographically located in Amhara National Regional State, North Gondar Administrative Zone, Telemte woreda.

Telemte woreda located at $609 \mathrm{k} . \mathrm{m}$ from the regional city Bahirdar and $327 \mathrm{k} . \mathrm{m}$ from the zonal town of Debark in north-east of Ethiopia. (Source; woreda government communication office). The starting point of the project road Gilibina keble which located 1480589N, 433077E and ends Besikiya which is located 1469157N, 447590E. (Field survey).

It links Gilibina, Akuna, Agita, Merwo, Eirne, Betele and Besikia kebles.

The proposed project road is in harmony with all the national development policies and strategies of Ethiopia, and fulfils all requirements set forth both by the Federal and Amhara Regional Governments.

The project road brings important social benefits to the local population residing in the direct and indirect influence area. However, most social benefits of the project road are difficult to assign monetary values but are clearly part of project assets and welcomed by local people as improvements in their everyday life (e.g. employment creation, better roads also for pedestrian, etc). On the other hand, some impacts may be temporarily undesirable (e.g. noise, detours, camps, etc.) and cause some negative impacts.

This land acquisition report builds on FDRE Constitution and Proclamation No.455/2005; and also on ERA's RPF and World Bank's policy on involuntary resettlement (OP/BP 4.12). The content of this RAP is within Ethiopia's existing legal and administrative framework.

The land acquisition report assesses the policy and legal documents, identifies households to be affected and also properties and assets to be impacted; and rehabilitation and compensation measures to be carried out for affected households.

\section{General Objectives of the Land Acquisition study}

The main objective of the land acquisition study is to identify all the land acquire for the implementation of the road project which include farm land, grazing land, forest brush land valleys and river and community access route, buildings, utility services, crops, brush area $\&$ other assets.

\section{Specific Objectives of the land acquisition}

The main objectives,

* Carrying out of detailed SIAs (Social Impact Assessments) in relation to the road under construction.

* Conducting necessary field observation, consultation and office studies, and investigations and detailed engineering designs.

* Review of the existing policies and development strategies, legal and institutional frameworks pertaining to the project; 


\section{Methodology of Land Acquisition Study}

The land acquisition study methodology were used carried out by reviewing the previous report and on the basis of data and information collected from primary and secondary sources such as survey and land acquisition geometry report. The collection of primary data is based on field level data and information gatherings and surveys; series of public and stakeholders consultations carried out with project affected persons, vulnerable people, local authorities, elders, religious leaders and experts from different sector offices.

The following principles were adopted for assessing the impact of the road on property:

* The right of way (ROW) corridor selected for the road project is normally $30 \mathrm{~m}$ wide (15 m either side of road centerline).

* In accordance with the federal and state governing law, proclamations, regulations and directives, for buildings, perennial crops and trees will be provided, according to their current value, in order to allow the occupant to rebuild to an equivalent standard of construction.

For agricultural land, two different situations may occur;

* The land is devoted to permanent plantations (i.e. fruit trees, etc.): since this type of cultivation represents an investment of several years before the first harvest and before being profitable in terms of revenue; an indemnification considering the initial establishment of the plantation, and the annual cost for maintenance is proposed for the land to be expropriated;

* The land is devoted to temporary cultivation (Vegetables, grains, etc.): since this type of cultivation is non-permanent, an indemnification considering the production rate and local sales prices is proposed for to be expropriate

\section{Project Location}

The proposed Gilibina_Akuna_Agita_Merwo_Besikiya road project is administratively located in Amhara National Regional State, North Gondar Administrative Zone, Telemte woreda. The woreda administrative center located at $609 \mathrm{k} . \mathrm{m}$ from the regional city Bahirdar and $327 \mathrm{k} . \mathrm{m}$ from the zonal town Debark in north-east of Ethiopia. (Source; woreda government communication office).

The road project links Gilibina, Akuna, Agita, Merewo Billa, Merewo Gibrial Eirne, Betele and Besikiya kebles. The starting point of the project road Gilibina keble which located 1480589N, 433077 Project sikiya keble which is located $1469157 \mathrm{~N}, 447590 \mathrm{E}$. (Field survey data)

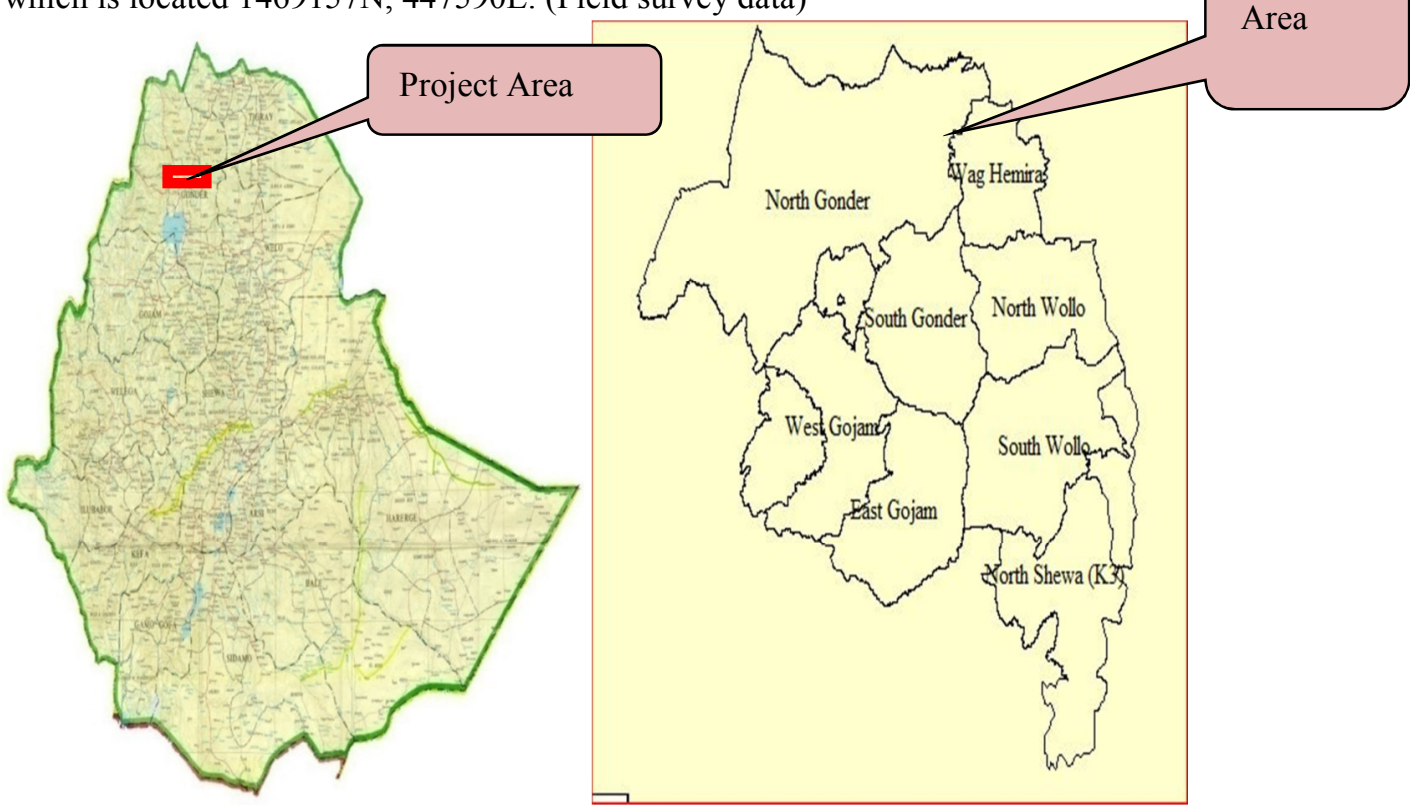

Figure 1 Road Project Location

\section{Literature Review}

\section{LAND ACQUISITION STUDY}

Land in Ethiopia is a state owned by proclamation no.31/1975, issued to deal with government ownership of rural land and proclamation no.47/1975, issued to cover government ownership of urban land.

Under Article 3(1) of the former proclamation, all rural land was to be the collective property of the Ethiopian people. Under article 4, any person who wished to cultivate land personally, was given rural land. This means that farmers are entitled to the use of land but Article 6 prohibits its transfer by mortgage or lease. Upon depth of the holder, the spouse or minor children of the deceased inherited only the rights to the use of the land. 
In 1994, the new constitution was approved. It retains land under the control of the people and government of Ethiopia thus prohibiting it's buying and selling, but ensure rights and allows for leasing of its rights to or from others.

\section{Legal, Policy and Administrative Policy Framework}

Currently there are a number of legal documents at Federal and Regional levels dealing with involuntary resettlement \& restitution. Previous legal documents which are consistent with the provisions of the F.D.R.E constitution are also checked. The major documents are proclamation No. 1/ 1995 of the Ethiopian Constitution, the 1997 Environment Policy, the Environmental Impact Assessment proclamation No. 299/2002, Environmental Impact Assessment Guideline Document (July 2000), Proclamation No. 455/2005 on Expropriation of Land holdings for Public Purposes and Payments of Compensations, Proclamation No. 456 / 2005 on Rural Land Administration and Land use Proclamation and Council of Ministers Regulations No. $135 / 2007$ on the payment of compensation for property situated on landholdings expropriated for public purposes. The Councils of Ministers Regulations No. 135/2007 is based on Article 14(1) of Proclamation No. $455 / 2005$ which states: "with a purpose of not only paying compensation but also to assist displaced persons to restore their livelihood". In this guideline an attempt has been made to summarize some of the provisions in these legal documents, which are found to be relevant to the present task. Hence, the present exercise subject to base these legal documents for identifications, valuation of damaged properties and rights for compensation payment procedures. In addition to these legal documents and regulations, major frameworks like ERA's Resettlement Policy Framework and World Bank procedures are checked for the preparation of this guideline.

The 1995 constitution of the Federal Democratic Republic of Ethiopia, article 40(2) and 40(3) stipulates public ownership of land and expropriation of land holdings for public purposes and payment of compensation. Proclamation No. 455/ 2005 specifically promulgated and provided provisions for compensations. The basic principle of ERA's Resettlement / Rehabilitation Policy Framework is to address the importance of compensation payments for the loss of assets at replacement cost, giving opportunities to locals to share project benefits and assisting PAPs' during relocation / rehabilitation. Detailed regulations for valuation of properties situated on landholdings expropriated for public purposes are promulgated on Council of Ministers Regulation No.135/2007. These legal documents have a more or less parallel similarity to the World Bank OP and BP 4.12.

Regarding compensations, all documents clearly state that individuals have the right to be compensated for the works on land created by labor, capital and land use rights. In line with these basic principles major resettlement and compensation issues are addressed from various legal documents as follows. However, if the national and international laws are in conflict, the latter overrules as to the World Bank policies for International Development Assisted projects.

\section{The Constitution}

As the major binding document for all other derivative national and regional policies, laws and regulations, the Constitution of the Federal Democratic Republic of Ethiopia, (FDRE), have provisions, which have a direct policy, legal and institutional relevance's for the appropriate implementation of resettlement action plans, which will be executed by the Ethiopian Roads Authority.

Article 40.3 of the Constitution declares public ownership of both rural and urban land as well as all natural resources. It further states that land is the common property of the Ethiopian people and cannot be subject to sale or to other means of exchange. Moreover, ownership of land is vested on the public and the people while rural and urban dwellers have only usufruct right over the land. A use right gives the user the right to use the land and the right to benefit from the fruits of her/his labour and capital which may be crops, trees, etc. found on the land or any other permanent works such as buildings etc.

Article 44.2 of the Constitution indicates that interventions for public goods that may cause the displacement of people or adversely affect the livelihood of the local population shall give the right to commensurate monetary or other means of compensation including relocation / rehabilitation with adequate state assistance. This provision has a strong relevance to the Resettlement Action Plans that ERA shall undertake while involved in road projects. The provisions in the constitution clearly states government's obligation not only to compensate for the loss of properties created by the labor and capital but also to compensate for the lost usufruct right over land through resettling the affected individuals/communities by the state programs with adequate assistances.

\section{Regional States Land Administration and Land Use Proclamation}

Based on the Federal land administration and utilization proclamation No.456 / 2005, (which repealed the Federal Government Rural Land Administration Proclamation No.89/ 1997); regions will commence their own land administration and utilization laws. Hence, the preparation of this RAP is obliged to adopt and used the Amhara and national regional state rural land administration and land use proclamation. 
According to the World Bank policy Research Working paper No. 4218, rural land certification in main regions of the country started in 2003. Up to the publication of the above mentioned research working paper in April 2007, 88\% of households in Tigray, 79\% in Amhara and 46\% in SNNPR were undergone the land registration process.

\section{Proclamation Number 455/2005}

Article $8(1)$ of this proclamation sates that a rural landholder whose landholding has been permanently expropriated shall be paid for his (her) displacement / rehabilitation options an amount equivalent to ten times (years) the average income he secured during the preceding past five years in addition to other payments like losing fixed assets, annual and perennial crops and cash crops. Again Article 8(2) stipulates that a landholder whose land provisionally expropriated shall be paid for the lost income, based on the average annual income secured for the preceding five years, until he/she repossesses the land. In accordance with this proclamation Article 14(1) provision which state "The council of Ministers may issue regulations necessary for the proper implementation of this proclamation" Regulation No.135/2007 is promulgated and effective as of $4^{\text {th }}$ day of July 2007. There is an expectation among professionals that this regulation might solve ambiguities related to valuation of properties and compensation payments. The valuation procedure for determining additional compensation, (like for permanent land improvement), is yet officially enacted. Those individuals who will get a land-to-land replacement shall be compensated for the loss an amount equivalent to the average annual income secured during the preceding five years.

As per this proclamation Article 8(4) urban landholder whose land holding has been expropriated shall be provided, apart from the estimated payment for the lost structures, with a plot of urban land to construct a structure and to be paid a displacement compensation equivalent to the annual rent of the demolished house or be allowed to live in public house without rent for one year.

In order to conduct an effective and full-fledged compensation for project-affected peoples, the enactment of the regulation has been essential. Article 19(1) of Regulation 135/2007 stipulates on properties for which compensation is not payable. As to this Article "there shall be no payment of compensation with respect to any construction or improvements made like buildings, any crops sown, perennial crops planted or any permanent improvement on land, where such activity is done after the possessor of the land is served with the expropriation order". The broad framework within Proclamation No. 455/2005 and regulation 135/2007 are binding in implementing valuation of properties and remuneration payments.

\section{Ethiopian Roads Authority (Policy Framework)}

Apart from the broad policy frameworks at national level, the main reference behind the preparation of this Resettlement Action Plan (RAP) is ERA's guiding principles as stipulated in its Resettlement and Rehabilitation Policy Framework. The principles in the framework are adopted basically from the World Bank's policy on resettlement and rehabilitation. The following statement is adopted from ERA's Resettlement and Rehabilitation Framework to show when and where a RAP is required or not.

Project identification, social screening/social impact assessment (SIA) of the subprojects will be conducted with the aim to determine whether or not a subproject requires detailed resettlement action plans as specified in World Bank policy. The principles of compensation/rehabilitation will be triggered wherever there will be a land requirement and adverse social impacts. If the SIA findings reveal that more than 200 persons are affected by a subproject, a resettlement action plan will be prepared (ERA 2013). However, as to OP 4.12, "where impacts on the entire displaced is minor, or fewer than 200 people are displaced, an abbreviated resettlement plan may be agreed with the borrower"

As per the above framework and the Bank policy, a threshold has been set whether or not to proceed with a detail RAP once a social screening is done on any proposed road development project. A Road development that entails the relocation of more than 200 individuals or above 40 households is expected to entail a resettlement action plan. Those road projects that would displace less than 200 individuals are not expected to come up with a detailed/full scale RAP. In such cases an Abbreviated Resettlement Action Plan shall be prepared. Although this is the case, there is a major gap between the National Legislations and the WB Operational Policies (OP4.12) in notification period and expropriation of properties. Proclamation No 455/2005 Article (3) (4) requires that property must be handed over 90 days after compensation has been paid. On the other hand OP.4.12 requires that displacement must not occur before necessary measures for resettlements are in place. In case of a conflict between the national and international procedures, OP4.12 states that" where domestic law does not meet the standard of compensation at full replacement cost, compensation under domestic law is supplemented by additional measures necessary to meet the replacement cost standard".

\section{Land use and the Right of Way}

Conceptually the term land use implies the function of land determined by natural conditions and human 
intervention. Usually it is categorized according to the status of the specific land and employment by human interventions. Land use in the present context upholds direct use as well as preservation, conservation, development and management.

Land in Ethiopia is the property of the state / public and does not require compensation. The land proclamation No. 31/1975 on rural land and No. 47/1975 of the urban land states that government holds the ownership of land; it is the property of the Ethiopian People. However, Article 7(72) of proclamation No $47 / 1975$ states that the government shall pay fair compensation for property situated on the land, but the amount of compensation shall not take any value of the land into account, because land is owned by state. The change to state ownership was enshrined in proclamation No.1 / 1987 and proclamation No. 1 / 1995. Moreover, the Federal Government issued the rural land administration proclamation (No. 456/2005) that vested power on regional states to enact regional laws to the purpose consistent with the principles and laws of the Federal government. According to this proclamation Article 17(1) "each regional council shall enact rural land administration and land use law, which consists of detailed provisions necessary to implement this proclamation".

Proclamation No.80/1997 article 6(18) states that ERA shall use, free of charge, land and such other resources and quarry substances for the purpose of construction of highways, camps, storage of equipment and other required services, provided however, that it shall pay compensation in accordance with the law for properties on the land it uses.

The Right-of-Way (RoW) is the land allocated and preserved by the law for public use in road construction, rehabilitation and maintenance work. For example in the RR50 standard 15mt width on either side of the road centerline fall into the legal RoW. In recognition of Article 6(17) of proclamation No.80/1997 in re-establishing ERA gave the mandate to "determine the extent of land required for its activities in the adjacency as well as surrounding of highways and the conditions of use of such land by others". However, this proclamation does not explicitly determine the extent of the Right of Way. Traditionally ERA exercises 30mt of ROW for its projects. As to this proclamation ERA has a mandate:

(a) To develop and administer highways,

(b) To ensure the standard of road construction and,

(c) To create a proper condition on which the road net- work is coordinately promoted.

On the other hand Proclamation No 455/2005, which is targeted on expropriation of land holdings for public purposes and payment of compensations, is the base for this RAP. For detailed regulations on valuation of properties situated on landholdings expropriated for public purposes, the RAP relied on Council of Ministers regulations No.135/2007.

\section{The World Bank Operational Policies (OP4.12)}

The Operational Policies of the World Bank on Involuntary Resettlement focused on to ensure project affected people especially the poor and vulnerable ones have more to say and participate as equal partners and to improve their livelihoods and standard of living or at least restore them in real terms. Moreover, it is geared towards to avoid or minimize adverse impacts of projects. The Bank experience indicates that development projects, if unmitigated, may cause severe long-term hardships, impoverishment, and environmental damages. Hence, the following are policy objectives of the World Bank as outlined in the aforementioned Operational Policies.

* Involuntary Resettlement should be avoided where feasible, or minimized, exploring all viable alternative project designs.

* Where it is not feasible to avoid resettlement, resettlement activities should be conceived and executed as sustainable development program, providing sufficient investment resources to enable the person displaced by the project to share in project benefits. Displaced persons should be meaningfully consulted and should have opportunities to participate in planning and implementing resettlement program.

* Displaced persons should be assisted in their efforts to improve their livelihoods and standards of living or at least to restore them, in real term, to pre-displacement levels or to levels prevailing prior to the beginning of project implementation, whichever is higher.

Moreover, as per OP4.12 footnote 1, the World Bank requirements for compensation must be followed with: "Where domestic law does not meet the standard of compensation at full replacement cost, compensation under domestic law is supplemented by additional measures necessary to meet the replacement cost standard". These conditions are applicable for all PAPs including squatters and illegally settled people except prospectors and intruders after the cut-off- dates.

\section{Results and Discussion of Road Project Negative Social and Economic Impacts}

There are number of negative impacts that influence the construction of the project road and some of the negative impacts could be avoided if proper mitigation measures are carried out. The negative impacts are 
related to expropriation of farm land, crop loss, spread of malaria, STD and HIV/AIDS, growth of squatters and uncontrolled settlements, noise disturbance, spoil dumping and pressure on local services and facilities, and impact on settlements.

\section{Impacts on urban and rural houses}

In road and other infrastructure projects, impact on houses that are either used for residential or business purposes due to the widening of existing ROW or construction of new roads is a common phenomenon. In the project road, 103 structures which include huts/houses/buildings will be fully affected by the project construction. The numbers of affected households due to loss of residence and business houses are about 103 male $=80$, female $=23$ which will be dislocated as the result the impact. The affected houses are mainly of constructed with wood, stone and mud and having either mud or CIS roofing. Most of the affected houses are located in Gilibina, Betel, Kallu and Merewo urban areas. (Field survey)

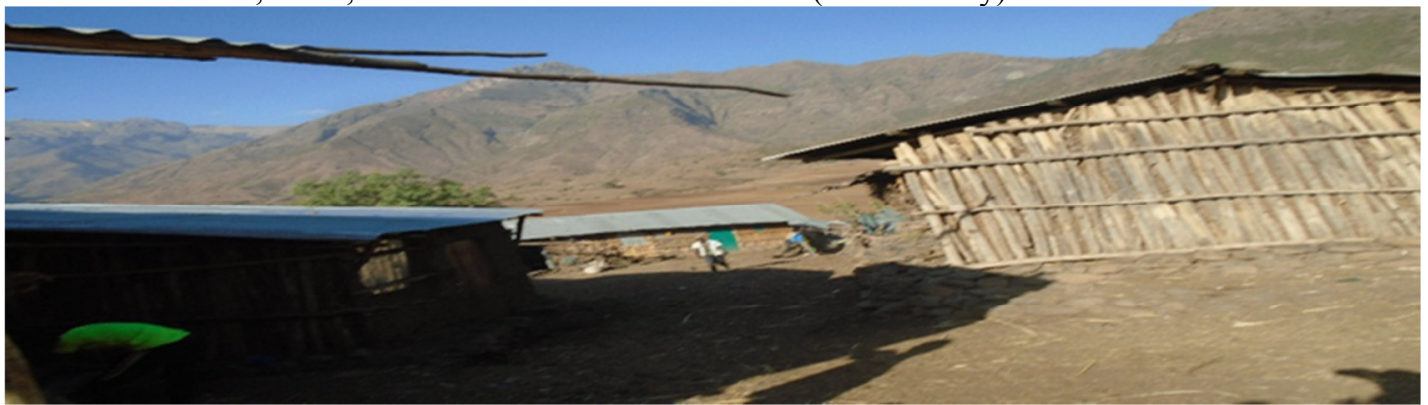

Figure 2 effect on houses at Gilibina urban village

\section{Boundary of Fences}

The fences of individual holdings, schools, churches and farmers training school are mostly made of wood and stone with wood and are partially affected during the construction of road project. These affected social service fence are usually located in urban areas of Gilibina, Mosebiay, Merewo, Betele and Kalu. However in the rural areas also individual holdings fences are affected by the road project.

The number of households who will have affected their fence by the road project are male $=28$, female $=10$ sum $=38$. (Survey report)

An estimation of total fences affected by the road will be $268 \mathrm{~m}^{3}$ and fence made of either wood or stone materials.

\section{Impacts of the Project on Farmlands}

The construction of new road project mainly demand new farm, grazing and brush and forest areas and hence, there will be much farmland that will be lost permanently. There will be also temporary lose farmland by households. The number of households who have affected their farmland due to road project are male $=333$, female $=23$ sum $=356$,

However, no single farming household will fully lose his/her farmland.

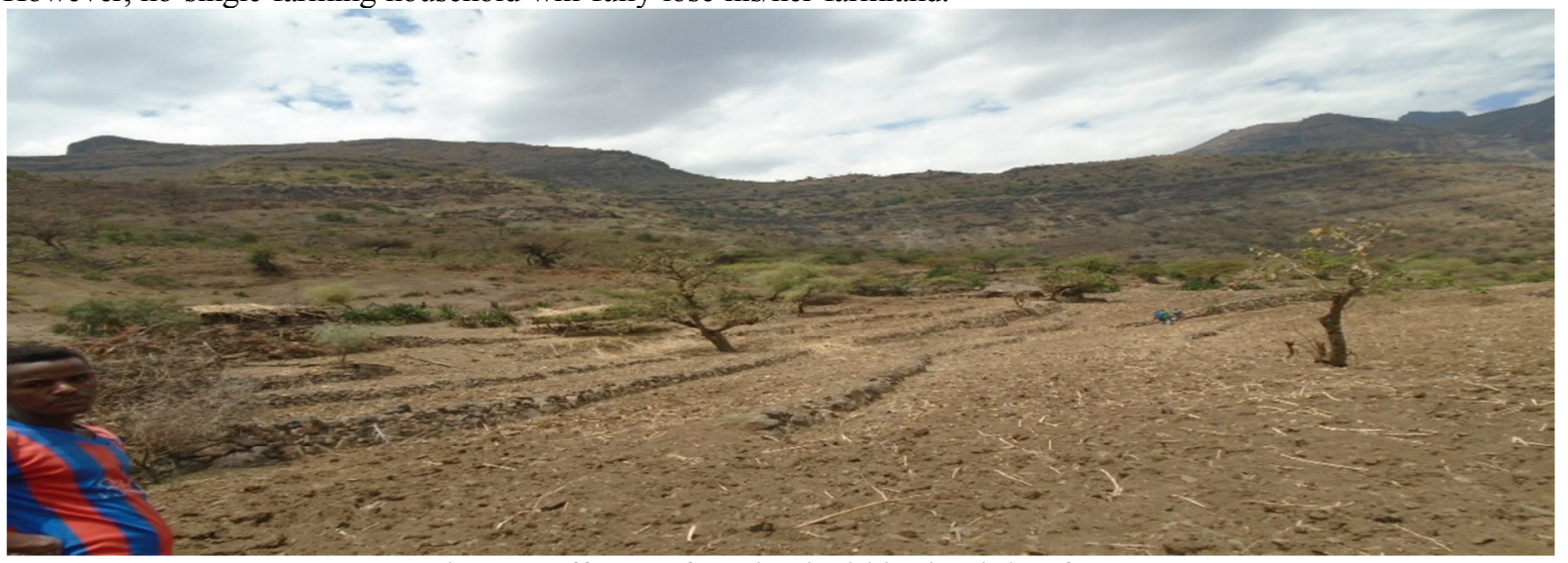

Figure 3 effect on farm land within the right of way

\section{Impact on perennial crops and Trees}

Field observation coupled and survey data show that the proposed road project has an impact natural tree. Since they existed with in the project right of ways. 


\section{Cultivated Area}

The construction of the road project has no access road will affect the farm land totally. However, there will be also temporary lose farmland by households.

An estimation of the total amount of farmland to be affected permanently by the project is estimated to be 34.5 hectares.

About 1234 strip of farm land will be affected, and consequently about 356 male $=333$, female $=23$ household heads will lose strip of farmland. However, no single farming household will fully lose his/her farmland. (Field survey)

The estimation unite cost of farm land per hectare will be 254,890 birr and total estimation compensation cost for the strip of farm land will be 8,793,705 birr.

Experiences from road projects reveal that, unless adverse social impacts, such as resettlement and relocation of PAPs are mitigated might lead to severe socio-economic impacts.

\section{Impacts of the Project on Social Services}

Disruptions of social services and amenities due to the project are virtually existent since there may exist along the route. Social service that affected by this road projects are school fence, church fence and electric pole since they exist along the proposed project right of ways.

On the other hand, the proposed project will have a great impetus on the development of these services and others like postal, internet and public transport.

The impact on social services such as schools and health centers exist in Merewo, Betel and Kalu urban villages.

\section{Utility line}

No public utilities that will be affected during the construction of the road project.

\section{Impacts associated with ancillary works}

Ancillary works associated with the road construction like quarry and borrow pits, construction camps and detour roads will dispossess certain grazing lands and trees. Normally such demands are temporary in nature and the land shall be reinstated to its original condition. However, past experience shows there is a negligence to reinstate these lands by the contractors. Moreover, camp sites as they remained for other services after the end of the project shall not be constructed on rich agricultural lands and ecologically sensitive areas. This RAP assumes the land required for temporary activities related to the road construction reinstated to their pre-project situation.

\section{Exposure to HIV / AIDS and other Sexually Transmitted Diseases (STD)}

In Ethiopia, the HIV/AIDS pandemic, in recent years, has emerged as a major health hazard, affecting mainly the age group of 15 to 49 years. HIV / AIDS emerged as a major health hazard in recent years in Ethiopia. Road construction and other similar type of project workers, and truck drivers are considered as having high potential (or good vectors) for the spread of Sexually Transmitted Diseases (STDs) and HIV/AIDS virus due to their mobility. This is partly because construction workers are mostly young and sexually active group of the population and are mobile, and are also forced to live in working camps.

Contacts and communications created between local communities and construction workers who have come to the project area from different localities and mainly from major towns will expose the local community to new and alien cultures and behaviors that might be against local cultures and behaviors.

The introduction of new and alien cultures and behaviors may contribute to the spread of communicable diseases such STD and HIV/AIDS. Similarly, other unwanted experiences such as, the coming of sex workers to the project area from major towns and cities will contribute to the increase in the number of sex workers, alcoholism and crime.

\section{Impact on Women}

In Ethiopia, there is high gender disparity and this is also believed to be one of the major bottlenecks for development. This high gender disparity between men and women negatively affects the development of a nation and its wealth distribution.

Among the negative social impacts, resettlement/relocation of PAPs may affect women more than men. Resettlement/relocation might lead to the breakdown of community social networks and this has direct impact on women in particular, because most rural women rely and depend on community and social networks for their emotional, family and practical supports

In road construction works, women always do not receive equal employment opportunities; and the contractors, in most cases, favour to employ men rather than women, and female workers do not obtain particular attention due to their biological and physical condition. 
Hence, the discrimination against women will negatively affect those women who want to work in the road construction work. Such discriminatory acts and lack of other employment opportunities may force women to carry out other marginal activities and to be engaged as sex workers for survival, which exposes them to increased risk of sexually transmitted diseases, HIV/AIDs and unwanted pregnancies.

The negative impacts of the project road on women include:

- Increased risk of exposure to sexually transmitted diseases and unwanted pregnancies,

- Price increase of consumer goods due to the coming of large number work force to the area in particular will make FHH vulnerable to economic crisis,

- Most construction companies prefer to employ only men, and this will lead to unequal treatment women during employment of the construction work force.

\section{Positive impact of the road project}

The potential positive social impacts from the construction of the project road will be employment creation, income generating activities, improved delivery of social services, and reduction of costs of transport, facilitate travel and transport within the project area. In addition, the improvement of the road will contribute to improved transport services and to increasing levels of travel and transport.

The major social benefits include the development of increased / improved trade and market facilities and improvement in the provision of social services; and employment opportunity created for women to work as labourers in the project road and also income generation through sales of goods and services to construction workers.

The delivery of social services, agricultural inputs, consumer goods will improve due to the construction of the project road and availability of better accessibility in the project area. The project road is important for access to health facilities, schools, major market centres, agricultural input supplies stores and other service giving institutions.

The construction of the project road will create subsequent increase and utilization of agricultural inputs and services that will result in increased production, higher farm gate prices for local produce, resulting in higher incomes to the farming households.

It is also expected that employment opportunities for the local labour force will be created; it can be assumed that this will be a significant contribution to the reduction of poverty at the household level.

The project road, in its short and medium term will create impacts such as reductions in vehicle operating, transport and time costs for public passenger and freight transports and for private vehicle users, and improvement in the availability of transport facilities and services.

In the long term, development impacts and incentive will be created that will bring about economic growth and changes in the livelihood conditions of the people residing in the project area. It is anticipated that due to the upgraded road more new businesses and investment projects would be coming up in the project area. It is also true that qualified personnel will be attracted to work in the project area with the improvement of road accessibility, improved transport service and also with the availability and timely delivery of the required services.

\section{Crop Production}

Farming is the major source of income of the majority population of the project woreda in general and that of along the proposed road project kebles in particular

The farming system is dependent on small holder farming which is mainly practiced through traditional methods of hoe cultivation and oxen plough.

Crop production in the project woreda in general and along the proposed project kebles in particular predominately carried out under rain-fed, with only small fragmented part being irrigated for vegetables, crops and fruits. (woreda agriculture office).

Rain-fed: Data from the woreda agriculture office show that the predominate Crops that produce with rainfed are surgam, teff, barely, wheat, peas, beans, maize, potato, lentil, chickpea, and cash crop small part of the area sesame, white onion in the woreda and the along project kebles predominate are crops sorghum, maize, teff, wheat, barley, beans, peas and cash crops small part of the area sesame and white onion etc.

As the reporter consulted the woreda agriculture head office and data from the office imply that the main constraints for agriculture production and productivity are lack of road access leads agricultural in-puts and extension package not arrived at the intended time, along the project kebles farmers training school not properly constructed and poor in-put facilities.

Along the project kebles food insecurity challenge since the non-existence of road access aggravate these problem.

Irrigation: data from the woreda irrigation team show that Telmete woreda has potential for irrigable rivers and land. The major rivers that used for irrigation are Atibe, Benibiya, Tekeze, Abore, Goshe, Migasa, 
Abayarid, Amogne, Mosibiya and Beskiya rivers. Data from the woreda agriculture office imply that total 2,199 hectares of land has developed with irrigation. Along the project kebles the irrigable rivers are Binibiya, Amogne, Abore, Mosibiya and Goshba and total 934 hectares of land has irrigated (field observation and woreda irrigation team).

The type of crop produce with irrigation are garlic and onion, pepper corn, tomato, sugar cane, cabbage, coffee and orange in the woreda and the same too along the route. (woreda irrigation team 2009 data).

During the transect walk I have seen that the river Benibiya has divert using small scale irrigation canal and has developed the area shown the photo below.

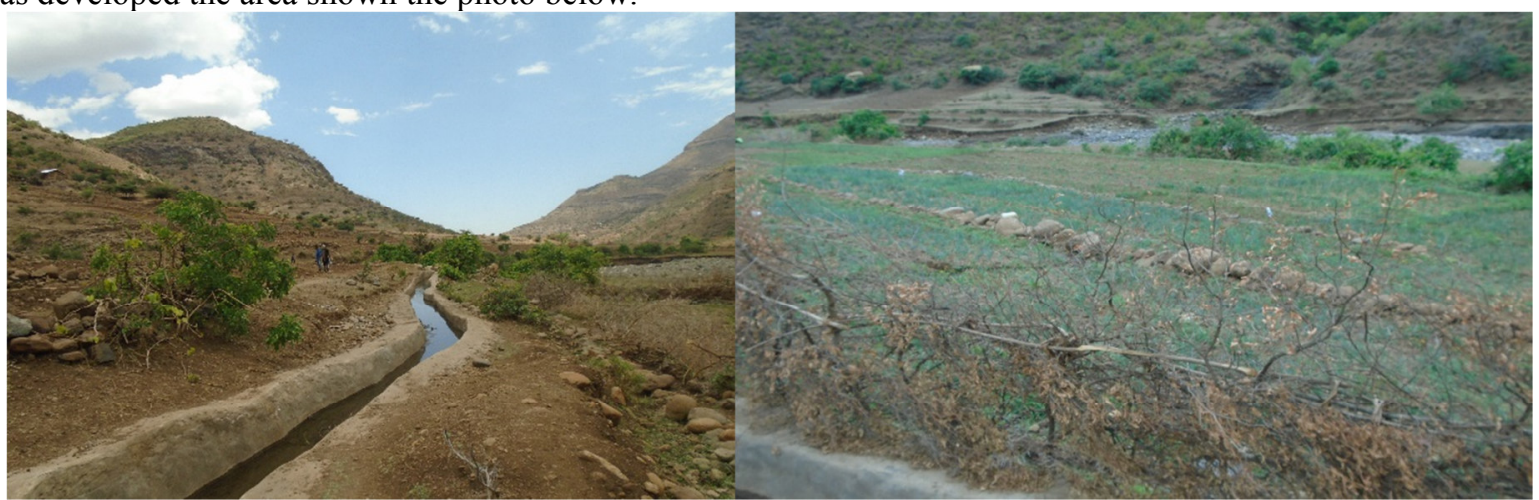

Figure 4 Irrigation along proposed road project using Benibiya river diversion

During public discussion the Keble's community said that using the river Binibiya, Atibe and Besikiya we irrigated fruits and vegetables but lack of access road our cash crop and irrigable product cannot get sufficient market and we cannot get agricultural input such as fertilizers and selected seeds at the peak time of agriculture period.

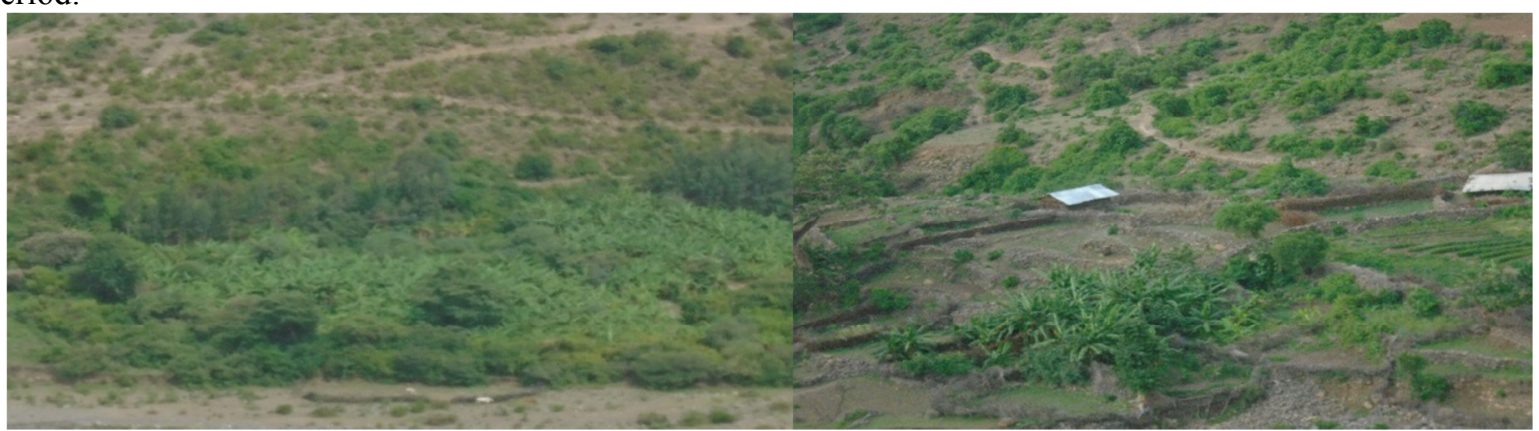

Figure 5 Irrigated banana, papaya and coffee using river Benibiya.

\section{Animal husbandry}

Animal husbandry is the second main source of income of the woreda population in general and along the proposed project kebles in particular.

Data from the woerda livestock resource office imply that the woreda has potential of goat rearing as shown photo.

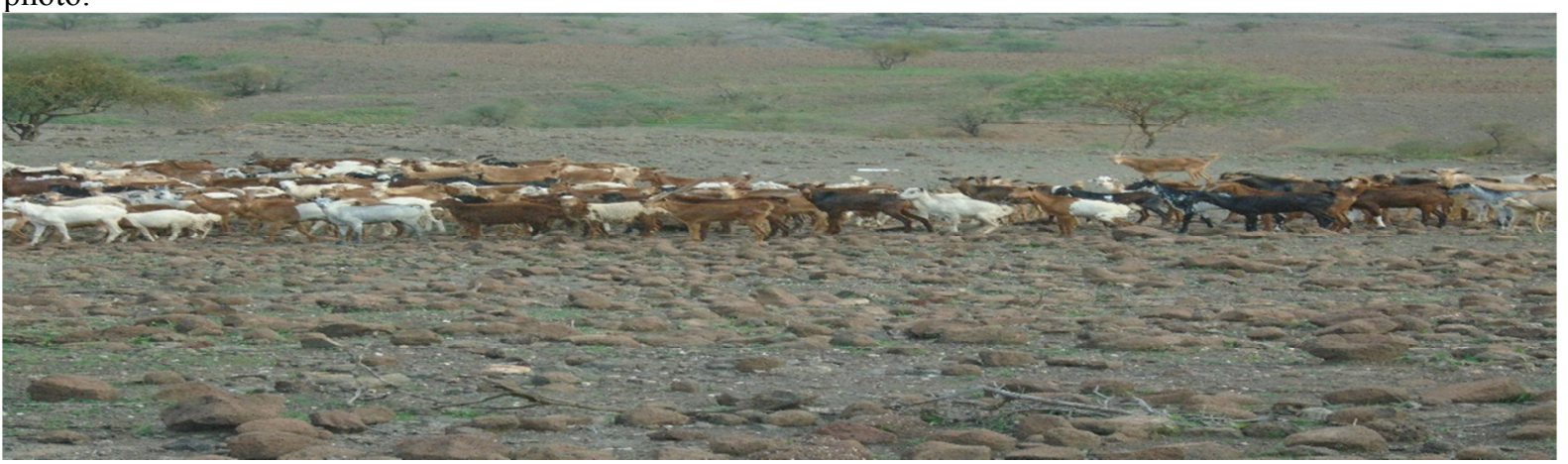

Figure 6 goat rearing at the proposed project kebles

And the same too along the proposed project kebles.

According to data from the woreda livestock resource the total numbers of livestock population in the project woreda and along the proposed project kebeles are as follow. 
Table 4 Show the total number of livestock population in the project woreda and kebles.

\begin{tabular}{|c|c|c|c|c|}
\hline Sr.no & \multicolumn{2}{|c|}{ Cattle population } & Numbers in the project woreda & along project kebles \\
\hline 1 & \multicolumn{2}{|c|}{ Bovine } & 56,968 & 17,349 \\
\hline 2 & \multicolumn{2}{|c|}{ Equine } & 10,285 & 4,602 \\
\hline 3 & \multirow[t]{2}{*}{ Ovine } & Sheep & 61,295 & 9,020 \\
\hline 4 & & Goat & 120,310 & 29,376 \\
\hline \multirow[t]{2}{*}{5} & \multicolumn{2}{|l|}{ Camel } & 15 & 10 \\
\hline & \multicolumn{2}{|l|}{ Total } & 348,873 & 60,357 \\
\hline
\end{tabular}

Source: project woreda livestock resource office

Discussion with the woreda livestock resource experts and the above secondary data show that the project woreda has potential for goat population and same to along the proposed road project kebles then specialization goat rearing advisable for the community. The woreda also has potential of fish resource at the river Binibiya and Tekze artificial Lake.

Secondary data from the woreda livestock resource office impel that Tekeze artificial lake has potential for fish production at per day 1,200 kilogram fish produce. The data also show that the woreda has potential honey production per annum 140.99 ton of honey produce.

But the non-existence of road access the fish, goat rearing and honey product not access market in central part of the region. They sell at less cost even the product may spoil.

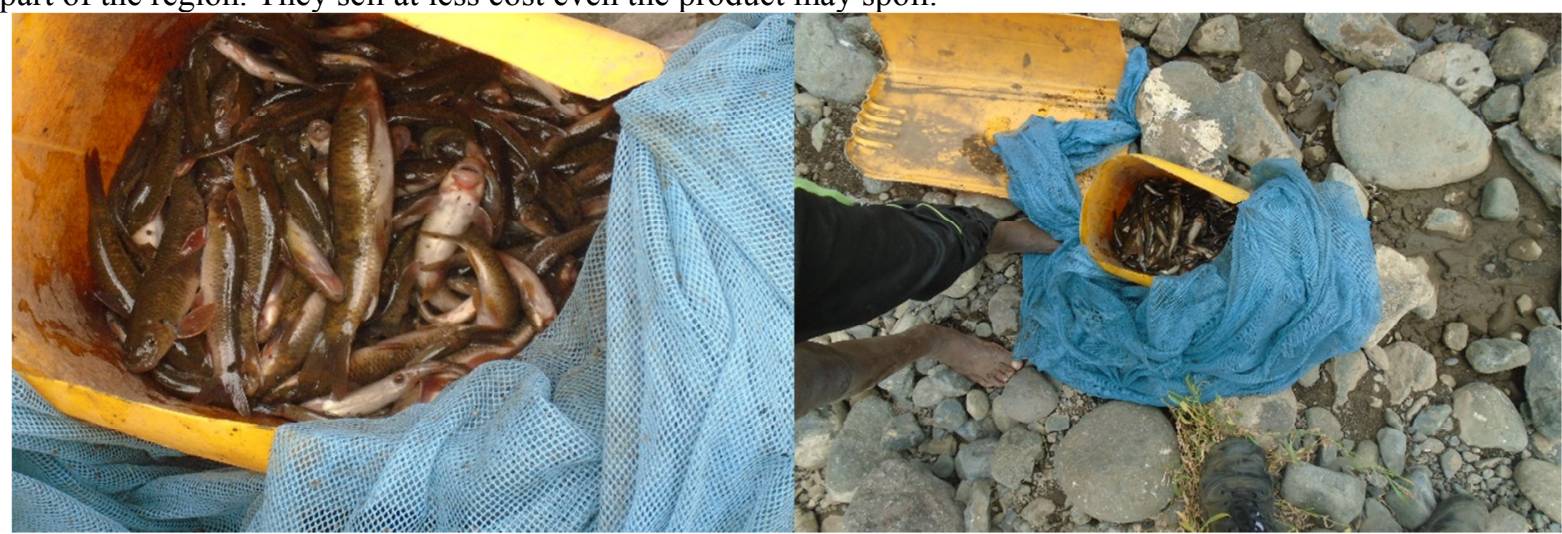

Figure 7 shown traditional fishery at the river Benibiya along road project kebles

As data shown the project woreda has potential in fish production, goat rearing and honey production and the same to along the project kebles. The local community should specialize in those areas and escape from food insecurity.

As the proposed road project will be constructed the community along the route will benefited by using improved livestock resource especially in fishery, honey production, easily access to get animal health, access market for the product from the animal.

The food insecurity level will be decline (achieve food secure) by these local potential along the proposed kebles community.

\section{Small and Microenterprise}

In Ethiopia, a study undertaken by the Central Statistical Agency (CSA) disclosed that there were about 974,679 micro enterprises, generating a means of livelihood for about 1.3 million people (CSA, 2002). Another study conducted in 2003 by CSA also revealed that 1,863 SMEs had created employment opportunities for about 97,782 citizens (CSA, 2003).

Data from the woreda small and microenterprise show that the enterprises found at woreda are service, manufacturing, sub agriculture, construction and trade.

The above data show that the size of small and micro enterprise too small and the number of employment opportunity created by those enterprises are small. Any respected body should encourage those enterprise.

As the proposed road project will be constructed temporary, daily and permanent employment will be created for the local community even capital will be create for the local community.

During the transect walk I have observed that the river Binibiya has potential for sand production.

As proposed road project will be constructed, the sand will create employment opportunity for the local youth. 


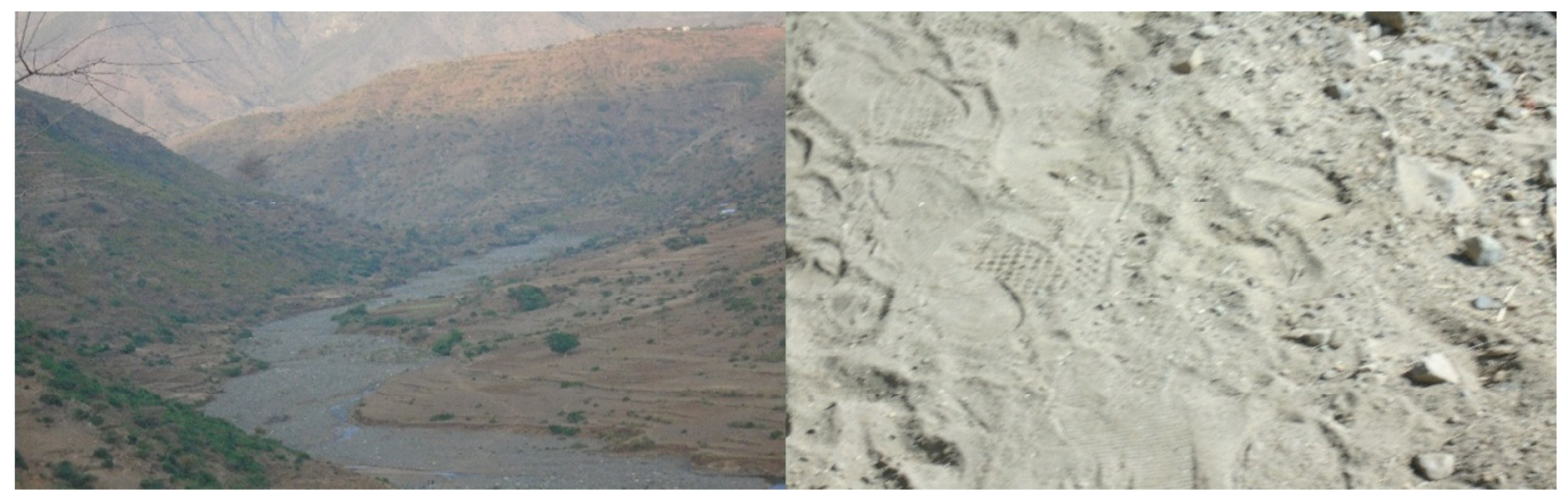

Figure 8 sand access at the river Binibiya along the road project kebles

\section{Social Services and Others Infrastructures}

In economic terms, road investment facilitates transportation system; it reduces freight and passenger charges, increases the size of vehicles using the road, and decreases vehicles operation cost and permits integration of markets and people. Furthermore, it is also very important in promoting and enhancing the socio economic development of social infrastructures such as health, education and others. Road construction influences the activity of the society traversing the area in terms of their settlement pattern, agricultural production, marketing system, social movements, cultural practices, etc.

In view of these, the writer has attempted to assess the level of basic social services in the woredas crossed by the road project kebles as follows.

\section{Health Services}

In the project area, there are five health centers and twenty two health posts and along the road project kebles are two health centers and seven health posts human health service and veterinary service are sixteen health post in the project woreda and five health posts along the project kebles.

\section{Educational Services}

When we look at distribution of education facilities and services in the project woreda and along the project kebles. In the project woreda there are thirteen elementary cycle (1-4), forty-three primary full cycle (1-8), one secondary schools (9-10) and one secondary and preparatory school. And along the project kebles are four elementary cycle (1-4), thirteen primary full cycle (1-8), one secondary (9-10) schools.

\section{Road and communication}

Field observation and data from the woreda road and transport office show that the woreda has seasonally connected to the zonal town Debark in to two ways.one way from Debark-Adirikaya after travelling of $180 \mathrm{k} . \mathrm{m}$ enter in Tigrie region to Mytebiriya-Dema-feiylewoha asphalt road after travelling 200k.m and before arriving feilwoha divert to west direction after travelling $30 \mathrm{k} . \mathrm{m}$ access road get Dejachi which was constructed by URRAP but access seasonally.

Another way from Adirikaya -Buye after traveling approximately $10 \mathrm{~km}$ asphalt road divert in the west direction traveling 67 k.m earth work road and get Dejachi now the road on construction which construct by NKH. Along the proposed project no road access.

The community use walking and puck animals as means of mobility to Dejachi town.

When we see the means communication at the woreda level have access wireless phone and mobile phone and along the project kebles have not access mobile telephone service but wireless present.

(iv). Clean water supply

Data from the Telemte woreda water office shows that the woreda clean water supply coverage achieved $52.5 \%$ and the number of population who used clean water supply were male $=26,700$, female $=24,033$ sum $=50,433$ at the same time numbers of clean water supply institutions were 167 of which 137 spring developed,10 deep dug well and 15 hand dug well.

Along the project kebles the number of clean water supply institutions and the number of clean water supply user population were 19 institution and male $=4,030$ female $=3,030$ sum 7,060 user respectively. (woreda water office basic water supply data).

Consultation with the head of woreda water supply office coupled with data from the office the main constraint clean water supply to supply in the project woreda in general and along the project kebles particular lack of rural road accesses as the result the local community travel more than six hour to get river water.

The community and we during the field observation drank the river water which was unsafe (unprotected) 
water.

We can see how the local community suffer with lack of clean water supply source as photo see below.

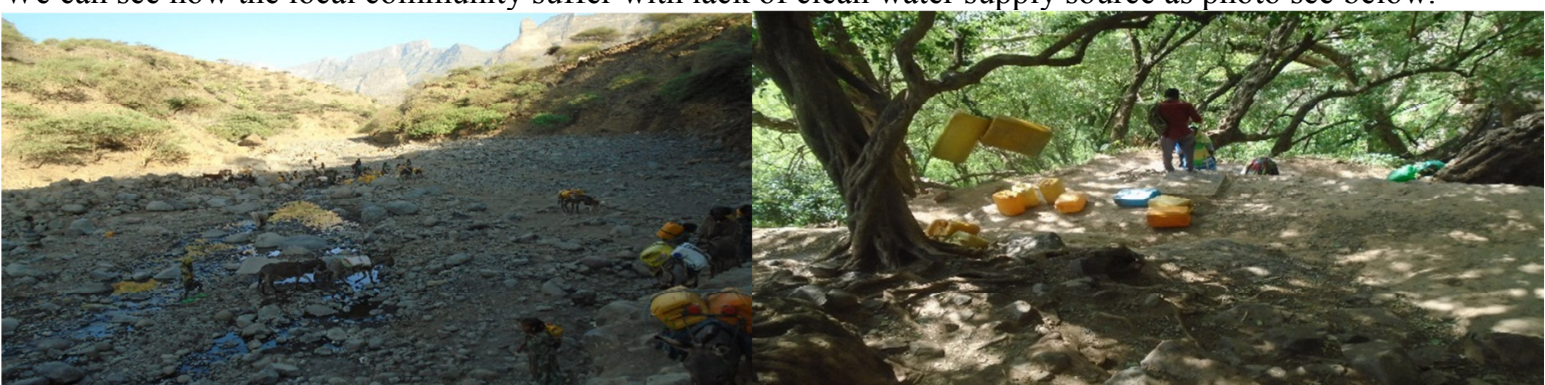

Figure 9 how the community suffer with clean water supply along road project kebles.

\section{(v) Hydroelectric power supply}

During the transect walk and data from woreda energy supply team indicate that non-kebles have got electric power supply including the Dijache urban woreda administrative center and the same too along the project kebles. But along the project and some kebles in the woreda used private generators and sun rise power supply privately and some social services such as health centres, posts and schools.

\section{(vi). Market center}

Market places are where goods and services exchanged. The community along the project kebles used more than two local market center at Gilibina keble (kidamigabia), Merawu keble center (kidamigabia) and end of the project at Kalu.

\section{(Vii). Financial institution}

Only Amhara credit and saving institution that gave credit and saving service for the woreda community. Along the project kebles the Amhara credit and saving institution has opened its satellite and give credit return and saving service.

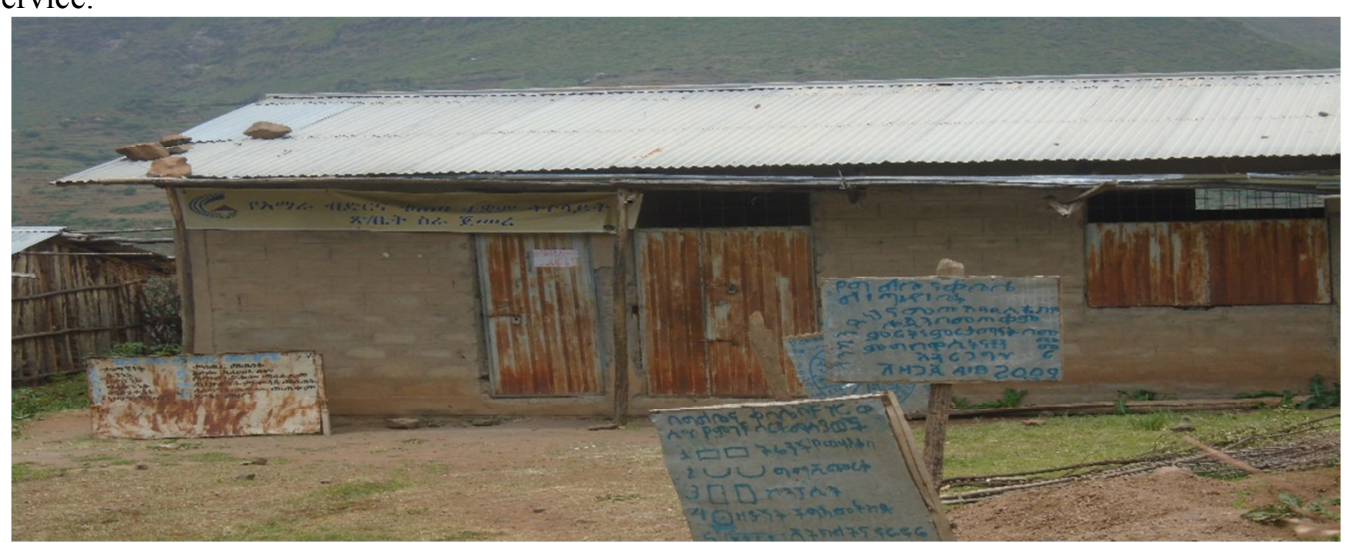

Figure 10 finical institution at the initial keble of the road project (Gilibina)

As the proposed road project will be construct, more number of finical institution, level and service of the finical institution will be encourage

\section{CONCLUSION AND RECOMMENDATION}

The proposed new road project will create better and improved socio economic development the local, regional and national and in particular better market opportunities for the sale of agricultural produce (crop and livestock) and consumer goods.

When the new road constructed it will create better market access for the local farmers, and their produces will fetch higher market prices in comparison to the current low prices. Further, due to the introduction and availability of improved road infrastructure trade and business will flourish and employment level also will be increased. The local economy would also show growth with the development of small business, investment projects; growth of urban centers, improved and efficient communication system, exposure to the advancement of technology and science through improved means of production. In general, employment opportunities will be created in the project area with the growth of the economy and improvement in the social services.

The local authorities and population residing in the project area would like the construction of the road to start without much delay. In all the public consultations held with different groups of the local community, and government officials as well as experts working in the project area, it was clear that the local population, PAPs and other stakeholders have expressed positively about the construction of the project.

The proposed project road is in harmony with all the national development policies and strategies of 
Ethiopia, and fulfils all requirements set forth both by the Federal and Regional Governments. The construction of the project road could be successfully implemented if it properly addresses both the positive and negative social impacts that would be created during the implementation of the project.

Most social benefits are difficult to assign monetary values but are clearly part of project assets and welcomed by local people as improvements in their everyday life (e.g. less dust, better roads also for pedestrians). Some impacts may be temporarily undesirable (e.g. noise, detours, camps, etc.)

On the other side, the construction of the project road would create some negative impacts on the local population. The negative impacts are mainly loss or reduction of productive assets, such as, loss of strip of farm land and income; loss of housing; loss of perineal crops and annual crops, spread of communicable diseases, the spread of HIV/AIDS, growth of squatters and uncontrolled settlements, traffic accidents and injuries.

\section{Reference}

A proclamation to provide for the expropriation of landholdings for public purposes and payment of compensation; proclamation No.455/2005

Constitution of the Federal Democratic Republic of Ethiopia Proclamation No.1/1995.

Council of Ministers Regulations No. 135. $/ 2007$ council of ministers regulations on the payment of compensation for property situated on landholdings expropriated for public purpose.

Detailed Engineering Design and tender document preparation for DERA -MECHARA road upgrading project. Environmental Impact Assessment, Wilbur Smith Associates in Association with Pan African Consultants, July 1998, Addis Ababa, Ethiopia.

Ethiopian Roads Authority, Environmental Procedures Manuals, 2001, Addis Ababa, Ethiopia.

Ethiopian Roads Authority, Resettlement/Rehabilitation Policy Framework, February 2002, Addis Ababa, Ethiopia.

Feasibility and EIA study, detailed engineering design and tender document preparation of jima - chida road project; final revised resettlement action plan (RAP) October, 2016.

Feasibility Study of RSDP II: Seven Roads Projects: Final Study Report, Volume 1, 1999, Kocks Consult GMBH Consulting Engineers in association with Metaferia Consulting Engineers, Addis Ababa, Ethiopia.

Road Sector Development Program Support Project (February 2007);Resettlement /réhabilitation Policy Framework.

Road Sector Development Programme 1997-2007. Second Draft Final Report. Ethiopian Roads Authority, Addis Ababa, January 1996 